\title{
Desulfovibrio marrakechensis sp. nov., a 1,4- tyrosol-oxidizing, sulfate-reducing bacterium isolated from olive mill wastewater
}

\author{
Correspondence \\ Abdel-Illah Qatibi \\ qatibi@fstg-marrakech.ac.ma \\ or \\ qatibi@yahoo.fr
}

\begin{abstract}
Fatima Chamkh, ${ }^{1}$ Cathrin Spröer, ${ }^{2}$ Paulo Costa Lemos, ${ }^{3}$ Stephane Besson, ${ }^{3,4}$ Abdel-Ghani El Asli, ${ }^{5}$ Rhizlane Bennisse, ${ }^{1}$ Marc Labat, ${ }^{6}$ Maria Reis ${ }^{3}$ and Abdel-Illah Qatibi ${ }^{1}$

${ }^{1}$ Anaerobic Microbiology Team (E02B26), Sciences and Techniques Faculty, Cadi Ayyad University, PO Box 549, 40000 Marrakech, Morocco

${ }^{2}$ DSMZ - Deutsche Sammlung von Mikroorganismen und Zellkulturen GmbH, Inhoffenstraße 7B, D-38124 Braunschweig, Germany

${ }^{3}$ REQUIMTE/COFB, Departamento de Química, FCT/UNL, 2829-516 Caparica, Portugal

${ }^{4}$ Unidade de Investigação em Biodiversidade e Desenvolvimento, Universidade Lusófona de Humanidades e Tecnologias, Campo Grande 376, 1749-024 Lisboa, Portugal

${ }^{5}$ School of Science and Engineering, Al Akhawayn University, PO Box 1846, Ifrane, Morocco

${ }^{6}$ IRD, UMR180 LMBEC, Université de Provence et de La Méditerranée, ESIL, Case 925, 163 Avenue de Luminy, F-13288 Marseille, France
\end{abstract}

\begin{abstract}
A novel mesophilic sulfate-reducing bacterium, $\mathrm{EMSSDQ}_{4}{ }^{\top}$, was isolated from olive mill wastewater in the semi-arid region of Morocco (Marrakech). Cells were Gram-negative, catalasepositive, straight rods that were non-motile and non-spore-forming and contained cytochrome $c_{3}$ and desulfoviridin. The DNA G $+C$ content was 65.1 mol\%. Phylogenetic analysis based on $16 \mathrm{~S}$ rRNA gene sequences revealed that the isolate was a member of the genus Desulfovibrio with Desulfovibrio carbinoliphilus D41 ${ }^{\top}$, Desulfovibrio alcoholivorans $\mathrm{SPSN}^{\top}$, Desulfovibrio fructosivorans $\mathrm{JJ}^{\top}$ and Desulfovibrio carbinolicus EDK82 ${ }^{\top}$ as the most closely related strains with validly published names. In addition to the classical substrates used by Desulfovibrio species, the isolate oxidized 1,4-tyrosol, one of the most abundant phenolic compounds occurring in olive mill wastewater, to 4-hydroxyphenylacetate without ring cleavage. D. alcoholivorans $\mathrm{SPSN}^{\top}$ was also found to carry out this reaction. Under air, strain $\mathrm{EMSSDQ}_{4}{ }^{\top}$ exhibited limited growth on lactate and yeast extract in the absence of sulfate. On the basis of genotypic and phenotypic characteristics, it is proposed that the isolate represents a novel species, Desulfovibrio marrakechensis sp. nov. The type strain is $\mathrm{EMSSDQ}_{4}{ }^{\top}\left(=\mathrm{DSM} 19337^{\top}=\mathrm{ATCC}^{\mathrm{B} A A}-1562^{\top}\right)$.
\end{abstract}

Olive oil manufacturing results annually in the production of more than $3 \times 10^{7} \mathrm{~m}^{3}$ black olive mill wastewater (OMW), which has a high polluting organic load due to the high content of organic substances, including sugars, tannins, polyphenols, polyalcohols, pectins, lipids and a

The authors dedicate this paper to the memory of Professor Norbert Pfennig (1925-2008).

Abbreviation: OMW, olive mill wastewater.

The GenBank/EMBL/DDBJ accession number for the 16S rRNA gene sequence of strain $\mathrm{EMSSDQ}_{4}{ }^{\top}$ is $\mathrm{AM} 47130$.

Photomicrographs of cells of strain $\mathrm{EMSSDO}_{4}{ }^{\top}$ and growth curves of strain $\mathrm{EMSSDO}_{4}{ }^{\top}$ and related strains cultivated in air in the absence of sulfate are available as supplementary material with the online version of this paper. wide variety of simple aromatic compounds, resulting from olive cell-wall degradation during the oil extraction process (Labat et al., 2000; Lesage-Meessen et al., 2001). OMW is frequently discharged into evaporation ponds, dumped directly in rivers or spread on soil, resulting in a major environmental problem in the main olive-producing countries of the Mediterranean region, mainly those in the south, such as Morocco. Microbiological studies on OMW and digesters treating these effluents have revealed the presence of metabolically diverse anaerobic bacteria (Mechichi et al., 2000; Chamkha et al., 2001; Thabet et al., 2004), all of which have been identified as anaerobic species belonging to the genus Clostridium.

In the course of a study on microbiological biodiversity in an aeration basin (a very large pond used formerly as an 
underground gallery for water for irrigation of the desert) located $10 \mathrm{~km}$ north-east of Marrakech city in Morocco $\left(31^{\circ} 38^{\prime} 52^{\prime \prime} \mathrm{N} 7^{\circ} 54^{\prime} 7.3^{\prime \prime} \mathrm{W}\right)$ and used to treat OMW by natural evaporation, several aerobic and anaerobic bacteria that are resistant to the simple aromatic compounds present in these effluents have been isolated and characterized. One of them has been identified recently as belonging to a new genus (Liebgott et al., 2008) and is a Gram-positive, anaerobic, rod-shaped, spore-forming bacterium that is unable to carry out dissimilatory sulfate reduction. In the present paper, strain $\mathrm{EMSSDQ}_{4}{ }^{\mathrm{T}}$, a novel Gram-negative, anaerobic, straight-rod-shaped, non-sporeforming, sulfate-reducing bacterium that oxidizes 1,4tyrosol to 4-hydroxyphenylacetate, which was isolated from the same OMW evaporation pond, is described. To our knowledge, this is the first bacterium to be described that is capable of performing this metabolic process. 1,4Tyrosol is one of the major simple aromatic compounds present in OMW (Fernandez-Bolanos et al., 1998; Mulinacci et al., 2001) and exhibits toxicity towards several micro-organisms (Capasso et al., 1995; Sayadi et al., 2000). It has been reported that only aerobic bacteria under oxic conditions are able to oxidize 1,4-tyrosol (Allouche et al., 2004; Abdelkafi et al., 2005; Liebgott et al., 2007).

The basal medium used consisted of $\left(1^{-1}\right.$ distilled water $)$ : $0.5 \mathrm{~g} \mathrm{~K}_{2} \mathrm{HPO}_{4}, 0.5 \mathrm{~g} \mathrm{KH}_{2} \mathrm{PO}_{4}, 0.5 \mathrm{~g} \mathrm{NH}_{4} \mathrm{Cl}, 0.4 \mathrm{~g} \mathrm{NaCl}$, $0.05 \mathrm{~g} \mathrm{CaCl}_{2} .2 \mathrm{H}_{2} \mathrm{O}, 0.3 \mathrm{~g} \mathrm{MgCl}_{2} \cdot 6 \mathrm{H}_{2} \mathrm{O}, 0.1 \mathrm{~g} \mathrm{KCl}, 0.25 \mathrm{~g}$ cysteine hydrochloride, $0.1 \mathrm{~g}$ yeast extract (Difco), $1 \mathrm{ml}$ trace element mineral solution (Widdel \& Pfennig, 1981) modified by Imhoff-Stuckle \& Pfennig (1983) and $1 \mathrm{ml}$ $0.1 \%(\mathrm{w} / \mathrm{v})$ resazurin. The $\mathrm{pH}$ was adjusted to 7.2 with $10 \mathrm{M} \mathrm{KOH}$. Unless otherwise indicated, aliquots of $9 \mathrm{ml}$ were dispensed into Hungate tubes under a stream of $\mathrm{O}_{2}$ free $\mathrm{N}_{2} / \mathrm{CO}_{2}(80: 20, \mathrm{v} / \mathrm{v})$ gas, closed with butyl rubber stoppers and subsequently autoclaved. Prior to inoculation, $\mathrm{NaHCO}_{3}(30 \mathrm{mM}), \mathrm{Na}_{2} \mathrm{~S} .9 \mathrm{H}_{2} \mathrm{O}(1.7 \mathrm{mM})$ and $1 \mathrm{ml}$ filtersterilized vitamin solution $1^{-1}$ (Balch et al., 1979) were added. For solid roll-tube media, $2 \%(\mathrm{w} / \mathrm{v})$ agar was added.

Samples of OMW (total content of phenols $2770-2820 \mathrm{mg}$ $1^{-1}$ ), collected as described by Liebgott et al., (2008) during the 2004-2005 harvest season at a depth of $60 \mathrm{~cm}$, were inoculated $(10 \%, \mathrm{v} / \mathrm{v})$ into basal medium containing $10 \mathrm{mM}$ lactate and $20 \mathrm{mM}$ sulfate and then incubated for 2-3 weeks at $37^{\circ} \mathrm{C}$. After several transfers under the same conditions and using repeated agar serial dilutions, brown colonies, approximately $1-2 \mathrm{~mm}$ in diameter, were observed within 1 week of incubation in agar roll-tubes (Hungate, 1969). Well-separated colonies were picked from the highest dilutions $\left(10^{-10}\right)$ and transferred to liquid basal medium containing $10 \mathrm{mM}$ lactate and $20 \mathrm{mM}$ sulfate. The purity of the culture was checked routinely by phase-contrast microscopy and by performing growth tests in basal medium containing $1 \%(\mathrm{w} / \mathrm{v})$ glucose, $1 \%(\mathrm{w} / \mathrm{v})$ yeast extract and $1 \%(\mathrm{w} / \mathrm{v})$ biotrypticase. Seven pure strains were obtained and subsequently shown to be similar by amplified rRNA gene restriction analysis profiles (data not shown). One strain, designated $\mathrm{EMSSDQ}_{4}{ }^{\mathrm{T}}$, was studied in detail. All physiological and metabolic tests were performed in triplicate at $37{ }^{\circ} \mathrm{C}$ (except for temperature experiments) using cells growing on lactate and sulfate. Unless otherwise indicated, positive growth was determined by monitoring changes in $\mathrm{OD}_{580}$ and by production of sulfides (Cord-Ruwisch, 1985), compared with negative controls.

Cells of strain $\mathrm{EMSSDQ}_{4}{ }^{\mathrm{T}}$ were non-motile, straight rods with rounded ends, approximately $1.3-1.6 \mu \mathrm{m}$ in diameter and 3-4 $\mu \mathrm{m}$ in length, occurring either singly or in pairs. Motility was not observed by optical microscopy, even in young cells during their first step of exponential growth. The isolate did not possess a flagellum, as clearly shown by electron microscopy (Supplementary Fig. S1, available in IJSEM Online). Cells were Gram-negative, oxidase-negative and catalase-positive. Spores were not observed either by microscopic examination or in heat-resistance experiments (Liebgott et al., 2007).

Optimal growth conditions were determined in basal medium containing $10 \mathrm{mM}$ lactate and $20 \mathrm{mM}$ sulfate as described by Qatibi et al. (1991). Optimum growth temperature was estimated to be $37^{\circ} \mathrm{C}$. No growth was observed at temperatures above $50{ }^{\circ} \mathrm{C}$ or below $20{ }^{\circ} \mathrm{C}$. Growth was optimal at $\mathrm{pH} 7$, with growth occurring between $\mathrm{pH} 6.5$ and 8.5. When tested at various $\mathrm{NaCl}$ concentrations, growth was observed between 0 and $35 \mathrm{~g} \mathrm{l}^{-1}$, with optimum growth in the absence of $\mathrm{NaCl}$.

Reduction of different electron acceptors was performed in basal medium with $10 \mathrm{mM}$ lactate and supplied with distinct electron acceptors: $20 \mathrm{mM}$ sulfate, $10 \mathrm{mM}$ sulfite, $10 \mathrm{mM}$ thiosulfate, $1 \%(\mathrm{w} / \mathrm{v})$ elemental sulfur, $5 \mathrm{mM}$ nitrate, $5 \mathrm{mM}$ nitrite and $10 \mathrm{mM}$ fumarate. Positive growth with the latter three electron acceptors was estimated by monitoring changes in optical density. In addition to sulfate, sulfite, thiosulfate, elemental sulfur and fumarate also served as electron acceptors. The isolate did not reduce nitrate or nitrite.

Because several aerobic bacteria were also isolated (see for example Liebgott et al., 2007) from the same site as strain $\mathrm{EMSSDQ}_{4}{ }^{\mathrm{T}}$, the capacity of the isolate to tolerate oxygen (air) was assessed; cysteine hydrochloride and sulfides were omitted from the basal medium for these experiments. Cultivation was carried out in tubes containing $4.5 \mathrm{ml}$ basal medium with $10 \mathrm{mM}$ lactate under an air atmosphere corresponding to two-thirds of the culture volume (the calculated amount of oxygen in the headspace was $80 \mu \mathrm{mol})$ and incubated horizontally using $10 \%(\mathrm{v} / \mathrm{v})$ inoculum growing in basal medium containing $10 \mathrm{mM}$ sulfate and $20 \mathrm{mM}$ lactate (to ensure that sulfate derived from the inoculum was completely consumed); after inoculation, the sulfide concentration was approximately $0.5 \mathrm{mM}$. Positive growth was determined by monitoring changes in optical density. In the presence of air, some limited growth $\left(\mathrm{OD}_{580} \leqslant 0.3\right)$ was observed in the absence of sulfate (Supplementary Fig. S2); the maximum growth 
rate and the doubling time were approximately $0.008 \mathrm{~h}^{-1}$ and $90 \mathrm{~h}$, respectively. Increased growth $\left(\mathrm{OD}_{580} \leqslant 0.47\right.$, $4.65 \mathrm{mM}$ sulfide) of the isolate on $10 \mathrm{mM}$ lactate in the presence of $20 \mathrm{mM}$ sulfate was observed as it shifted back to anaerobic conditions; the maximum growth rate and the doubling time were approximately $0.16 \mathrm{~h}^{-1}$ and $5 \mathrm{~h}$, respectively. Under aerobic conditions, cells became elongated (results not shown) and growth was poor or absent after a second transfer. From these preliminary tests, it can be assumed that the isolate was at least able to survive oxygen exposure. It would be interesting to investigate more fully whether oxygen served as a direct or indirect electron acceptor by the isolate.

Aromatic compounds (filter-sterilized) were tested at a final concentration of $5 \mathrm{mM}$ in modified basal medium with increased yeast extract $(0.05 \%, w / v)$ and $20 \mathrm{nM}$ sodium selenite; non-inoculated tubes were observed under the same conditions to verify that aromatic compounds were not partially transformed abiotically. In addition to sulfide production and optical density, positive growth was also determined by analysis of degradation products. Aromatic compounds were analysed by HPLC using a Waters apparatus composed of a 1525 binary pump, a 2996 diode array detector, a Rheodyne injector (model 7725i) fitted with a $20 \mu \mathrm{l}$ loop, a temperature control system and an in-line degasser. Separations were carried out on a Symmetry $\mathrm{C}_{18}$ reversed-phase column $(4.6 \times 150 \mathrm{~mm}$, ODS2, $5 \mu \mathrm{m}$ particle size). Elution was performed at $30{ }^{\circ} \mathrm{C}$ with a flow rate of $0.8 \mathrm{ml} \mathrm{min}{ }^{-1}$ using a linear gradient of acetonitrile (A) in water acidified with $1 \%$ $(\mathrm{v} / \mathrm{v})$ acetic acid (B) in two steps: the first step was from 5 to $20 \% \mathrm{~A}$ for $25 \mathrm{~min}$ and the second step was from 20 to $100 \%$ A for $5 \mathrm{~min}$ (total $30 \mathrm{~min}$ ). Aromatic compounds were visualized at $280 \mathrm{~nm}$ and total spectra from each peak were analysed from 200 to $400 \mathrm{~nm}$. Peaks were determined by comparing their retention times and respective UV spectra online (diode array detection) with commercial standards, except for $o$-methylgallate, which is not available commercially and was synthesized according to Scheline (1966).

Utilization of 21 simple aromatic compounds present in OMW in the presence of sulfate as electron acceptor was tested. Strain $\mathrm{EMSSDQ}_{4}{ }^{\mathrm{T}}$, Desulfovibrio alcoholivorans SPSN $^{\mathrm{T}}$, Desulfovibrio fructosivorans $\mathrm{JJ}^{\mathrm{T}}$ and Desulfovibrio carbinolicus $\mathrm{EDK} 82^{\mathrm{T}}$ were negative for utilization of phenol, catechol, resorcinol, 4-hydroxyphenylacetate, benzoate, 4-hydroxybenzoate, 3-hydroxybenzoate, protocatechuate, syringate, gallate, $o$-methylgallate, veratrate, $p$ anisate, cinnamate, $p^{-}, o^{-}$and $m$-coumarate, vanillate, ferulate and caffeate; the phenolic compound 1,4-tyrosol was utilized by strain $\mathrm{EMSSDQ}_{4}{ }^{\mathrm{T}}$ and $D$. alcoholivorans SPSN $^{\mathrm{T}}$ only (Table 1). 1,4-Tyrosol was oxidized by both these strains to 4 -hydroxyphenylacetate at $100 \%$ recovery leaving the aromatic ring intact (5 mmol 1,4-tyrosol was oxidized by strain $\mathrm{EMSSDQ}_{4}{ }^{\mathrm{T}}$ and $D$. alcoholivorans SPSN $^{\mathrm{T}}$ resulting in production of approximately $3.1 \mathrm{mmol}$ and $2.47 \mathrm{mmol}$ sulfide, respectively). These observations strongly suggest the following oxidation equation:

$\mathrm{C}_{8} \mathrm{O}_{2} \mathrm{H}_{10}+0.5 \mathrm{SO}_{4}^{2-} \rightarrow \mathrm{C}_{8} \mathrm{O}_{3} \mathrm{H}_{8}+0.5 \mathrm{~S}^{2-}+\mathrm{H}_{2} \mathrm{O}$

4-Hydroxyphenylacetate was not metabolized further by either strain even after more than 1 month of incubation. Under fermentation conditions, both strains were unable to utilize 1,4-tyrosol. It is interesting to note that, in the presence of sulfate, both strains were unable to metabolize other phenolic compounds such as, for example, unsubstituted phenol, 2-hydroxyphenol (catechol), 3-hydroxyphenol (resorcinol), 4-hydroxycinnamate, 4-hydroxybenzoate and 4-hydroxyphenylacetate, indicating that the composition and the position of the side chain were determinants for substrate specificity. A primary alcohol side chain in the para position to the hydroxyl group was required for the transformation of aromatic substrates.

When phylogenetic analysis revealed that strain $\mathrm{EMSSDQ}_{4}{ }^{\mathrm{T}}$ was related to some Desulfovibrio species (see below), other simple substrates commonly used by these bacteria were tested. Substrate utilization was tested in basal medium in the presence of $20 \mathrm{mM}$ sulfate (except for fermentation tests) containing different electron donors at a final concentration of $10 \mathrm{mM}$. Formate, methanol and hydrogen $\left(\mathrm{H}_{2} / \mathrm{CO}_{2}\right.$ at $\left.80: 20 \%, \mathrm{v} / \mathrm{v}\right)$ were tested in the absence or presence of $5 \mathrm{mM}$ acetate as carbon source. Yeast extract, peptone, Casamino acids and biotrypticase were tested at a final concentration of $0.5 \mathrm{~g} \mathrm{l}^{-1}$. Lactate and acetate were analysed by HPLC using a Bio-Rad Aminex HPX-87H column, with $0.005 \mathrm{M}$ sulfuric acid as eluent (elution rate of $0.6 \mathrm{ml} \mathrm{min}{ }^{-1}$ ) and an operating temperature of $50{ }^{\circ} \mathrm{C}$. A UV detector (Merck) set at $210 \mathrm{~nm}$ was used. Growth of the isolate occurred in the absence of vitamins or yeast extract after three transfers. Several non-aromatic substrates were used in the presence of sulfate including ethanol, 2methoxyethanol, 1-propanol, 2-propanol, 1-butanol, 1,2propanediol, 1,3-propanediol, 1,4-butanediol, hydrogen, formate, lactate, pyruvate, fumarate and malate. With the latter three substrates, small amounts of sulfide were produced $(\leqslant 1.5 \mathrm{mM})$. When sulfate was replaced by sulfite $(10 \mathrm{mM})$, which is the energetically more favourable electron acceptor, two to three times more sulfide was produced. Lactate was oxidized to acetate and presumably carbon dioxide. Growth with molecular hydrogen and formate required acetate as carbon source. Growth with formate, 1,4-butanediol and 2-propanol was weak. In the absence of sulfate, fumarate, malate and pyruvate could be fermented. No growth was observed on acetate, propionate, butyrate, methanol, 2-butanol, glycerol, ethylene glycol, 2,3butanediol, crotonate, alanine, glycine, arginine, lysine, choline, lactose, sucrose, glucose, fructose, maltose, mannose, ribose, xylose, yeast extract, biotrypticase, Casamino acids or peptone.

Pigments were assayed as described previously (Qatibi et al., 1991), except that cells were disrupted by ultrasound cycles and the resulting cell-free extract was concentrated in an Amicon ultrafiltration cell ( $10 \mathrm{kDa}$ pore size) before 
Table 1. Differential characteristics of strain $\mathrm{EMSSDQ}_{4}{ }^{\top}$ and type strains of related Desulfovibrio species

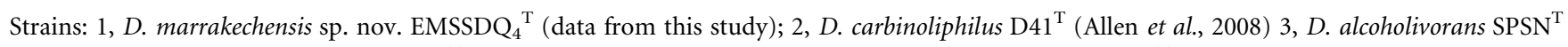
(Qatibi et al., 1991); 4, D. fructosivorans $\mathrm{JJ}^{\mathrm{T}}$ (Ollivier et al., 1988; Qatibi et al., 1991); 5, D. carbinolicus EDK82 ${ }^{\mathrm{T}}$ (Nanninga \& Gottschal, 1987; Qatibi et al., 1991). +, Positive; -, negative; $(+)$, weakly positive; ND, no data available.

\begin{tabular}{|c|c|c|c|c|c|}
\hline Character & 1 & 2 & 3 & 4 & 5 \\
\hline Morphology & Straight rods & Curved rods & Curved rods & Vibrioid rods & Rod-shaped \\
\hline Motility & - & + & + & + & - \\
\hline Cell diameter $(\mu \mathrm{m})$ & $1.3-1.6$ & $0.6-0.7$ & $0.7-0.9$ & $0.5-0.7$ & $0.6-1.1$ \\
\hline DNA G $+\mathrm{C}$ content $(\mathrm{mol} \%)$ & 65.1 & 63 & 64.5 & 64.1 & 65 \\
\hline \multicolumn{6}{|l|}{ Growth temperature $\left({ }^{\circ} \mathrm{C}\right)$} \\
\hline Optimum & 37 & 30 & $35-37$ & 35 & $37-38$ \\
\hline \multicolumn{6}{|l|}{$\mathrm{pH}$ for growth } \\
\hline Range & $6.5-8.5$ & $5.8-8.4$ & $5.5-8.5$ & ND & $5.3-8.7$ \\
\hline Optimum & 7 & $7-8$ & 7 & $6.5-7$ & $7-7.3$ \\
\hline \multicolumn{6}{|c|}{$\mathrm{NaCl}$ concentration for growth $\left(\mathrm{g}^{-1}\right)$} \\
\hline Range & $0-35$ & ND & $0-20$ & 0 to $<40$ & ND \\
\hline Methanol & - & $(+)$ & $(+)$ & - & + \\
\hline 2-Propanol & $(+)$ & $(+)$ & - & $-{ }^{\star}$ & - \\
\hline 2-Butanol & - & + & - & - & - \\
\hline Glycerol & - & - & + & + & + \\
\hline 1,2-Propanediol & $(+)$ & + & + & $-\dagger$ & $-\dagger$ \\
\hline Ethylene glycol & - & + & $(+)$ & + & + \\
\hline 1,4-Tyrosol & + & ND & $t^{*}$ & $-{ }^{*}$ & $-{ }^{*}$ \\
\hline Fructose & - & - & - & + & - \\
\hline \multicolumn{6}{|l|}{ Fermentation of: } \\
\hline Fumarate & + & - & + & + & + \\
\hline Malate & + & - & + & + & + \\
\hline
\end{tabular}

${ }^{\star}$ Tested in the present study.

$\dagger$ Degraded with glycerol as co-substrate in the absence of sulfate (Qatibi et al., 1998).

examination for cytochrome $c_{3}$ and desulfoviridin. The spectrum of the oxidized extract showed a characteristic absorption band at $629 \mathrm{~nm}$, indicating the presence of desulfoviridin. When reduced by sodium dithionite, the spectrum of cell-free extracts exhibited the characteristic absorption bands of cytochrome $c_{3}$, with maxima at 415.0, 522.5 and $553.0 \mathrm{~nm}$.

The DNA G + C content of strain $\mathrm{EMSSDQ}_{4}{ }^{\mathrm{T}}$, determined by HPLC (Mesbah et al., 1989) at the Identification Service of the DSMZ (Deutsche Sammlung von Mikroorganismen und Zellkulturen, Braunschweig, Germany), was $65.1 \mathrm{~mol} \%$, which is within the range reported for Desulfovibrio species (48-65 mol\%).
Phylogenetic analysis was carried out as follows. DNA from strain $\mathrm{EMSSDQ}_{4}{ }^{\mathrm{T}}$ was extracted using the DNeasy tissue kit according to the manufacturer's protocol (Qiagen). Purified PCR product was sequenced using the CEQTMDTCS-Quick Start kit (Beckmann Coulter) as directed in the manufacturer's protocol. Sequence reactions were electrophoresed using the CEQTM 8000 genetic analysis system. Primers F (5'-GAGTTTGATCCTGGCTCA-3') and R (5'-AGAAAGGAGGTGATCCAGCC-3') were used to amplify the $16 \mathrm{~S}$ rRNA gene. The nucleotide sequence was aligned manually using the sequence alignment editor ae2 (Maidak et al., 2001). Sequences used in the phylogenetic analysis were obtained from the RDP (Maidak et al., 2001) and GenBank (Benson et al., 1999). 
Pairwise evolutionary distances were calculated using the method of Jukes \& Cantor (1969). A dendrogram was constructed using the neighbour-joining method (Saitou \& Nei, 1987). Confidence in the tree topology was determined using 1000 bootstrapped trees (Felsenstein, 1985). Analysis of the complete sequence (1539 bp) of the $16 \mathrm{~S}$ rRNA gene of strain $\mathrm{EMSSDQ}_{4}{ }^{\mathrm{T}}$ revealed that the isolate was related to species of the genus Desulfovibrio in the family Desulfovibrionaceae in the Deltaproteobacteria. It represents a new sublineage (supported by a bootstrap value of $100 \%$ ) within the genus Desulfovibrio (Fig. 1) and, in particular, forms a subline with a subcluster of species consisting of Desulfovibrio carbinoliphilus D $41^{\mathrm{T}}$ (97.5\% sequence similarity with the type strain; Allen et al., 2008), D. alcoholivorans $\operatorname{SPSN}^{\mathrm{T}}$ (97.4\%; Qatibi et al., 1991), D. fructosivorans $\mathrm{JJ}^{\mathrm{T}}$ (97.2\%; Ollivier et al., 1988), $D$. carbinolicus EDK82 ${ }^{\mathrm{T}}$ (96.7\%; Nanninga \& Gottschal, 1987), Desulfovibrio burkinensis $\mathrm{HDv}^{\mathrm{T}}$ (96.0\%; Ouattara et al., 1999), Desulfovibrio magneticus RS- $1^{\mathrm{T}}$ (95.6\%; Sakaguchi et al., 2002) and Desulfovibrio sulfodismutans $\mathrm{ThAc01}^{\mathrm{T}}$ (94.2\%; Bak \& Pfennig., 1987) Strain EMSSDQ ${ }_{4}^{\mathrm{T}}$ shared a branching node with $D$. fructosivorans $\mathrm{JJ}^{\mathrm{T}}$, although this relationship was not supported by a statistically significant bootstrap value $(67 \%)$, demonstrating that this is not a particularly specific relationship. A $16 \mathrm{~S}$ rRNA gene sequence similarity of $97 \%$ is commonly considered as the upper limit for the definition of separate species (Stackebrandt \& Goebel, 1994). Although more than $97 \%$ similarity indicates that strains may belong to the same species, it is now generally acknowledged that this rule does not always apply for several Desulfovibrio species. Furthermore, Table 1 shows that strain $\mathrm{EMSSDQ}_{4}{ }^{\mathrm{T}}$ exhibited several characteristics that clearly distinguish it from closely related species with validly published names.

Strain $\mathrm{EMSSDQ}_{4}{ }^{\mathrm{T}}$ differed from D. carbinoliphilus $\mathrm{D} 41^{\mathrm{T}}$ (isolated from a gas condensate-contaminated aquifer), $D$. alcoholivorans $\mathrm{SPSN}^{\mathrm{T}}$ (isolated from a bioethanol production plant) and $D$. fructosivorans $\mathrm{JJ}^{\mathrm{T}}$ (isolated from estuarine sediment) in its cell shape and motility; unlike these three motile Desulfovibrio species, cells of strain $\mathrm{EMSSDQ}_{4}{ }^{\mathrm{T}}$ were non-motile, straight rods. Two species of non-motile, straight rods, D. carbinolicus and Desulfovibrio piger (Loubinoux et al., 2002), isolated from an anaerobic purification plant and human faeces, respectively, have already been included in the genus Desulfovibrio. Moreover, in contrast to the three motile Desulfovibrio species, the isolate did not possess a flagellum. It is improbable that the isolate was motile with a corkscrewlike motion as has been observed in some spirilloid Desulfovibrio species. Strain EMSSDQ ${ }_{4}{ }^{\mathrm{T}}$ also differed from D. carbinoliphilus $\mathrm{D} 41^{\mathrm{T}}$ in its DNA $\mathrm{G}+\mathrm{C}$ content, its temperature range and optimum temperature for growth, its inability to grow with methanol and 2-butanol and its ability to use fumarate and elemental sulfur as electron acceptors. Additionally, in contrast to D. carbinoliphilus $\mathrm{D} 41^{\mathrm{T}}$, the isolate fermented fumarate and malate. Strain EMSSDQ ${ }_{4}{ }^{\mathrm{T}}$ differed from D. alcoholivorans $\mathrm{SPSN}^{\mathrm{T}}$ by its temperature range and optimum salinity for growth, its inability to grow with succinate, methanol and glycerol and its ability to grow on 2-propanol and to use fumarate as electron acceptor. The isolate also differed from $D$. fructosivorans $\mathrm{JJ}^{\mathrm{T}}$ by its inability to use fructose and glycerol (in the presence or absence of sulfate) and its ability to use 1,2-propanediol, 1,4-tyrosol and 2-propanol. Unlike the non-motile D. carbinolicus $\mathrm{EDK} 82^{\mathrm{T}}$, strain $\mathrm{EMSSDQ}_{4}{ }^{\mathrm{T}}$ was unable to use methanol, glycerol (in the presence or absence of sulfate) and succinate, was able to use 1,2-propanediol, 1,4-tyrosol and 2-propanol as substrates and was able to use fumarate as electron acceptor. The temperature growth range also differed for the two strains. On the other hand, it is important to note that, even though $D$. alcoholivorans $\mathrm{SPSN}^{\mathrm{T}}, D$. carbinolicus $\mathrm{EDK}_{22}{ }^{\mathrm{T}}, D$. fructosivorans $\mathrm{JJ}^{\mathrm{T}}$ (present study) and Desulfovibrio magneticus RS- $1^{\mathrm{T}}$ (Sakaguchi et al., 2002) were also catalase-positive, they could not be cultivated in the presence of oxygen (air). This enzyme was supposed to be one of the two enzymes responsible for hydrogen peroxide elimination in Desulfovibrio species (for reviews see Dolla et al., 2006 and references therein).

Our data strongly indicate that strain $\mathrm{EMSSDQ}_{4}{ }^{\mathrm{T}}$ represents a novel species belonging to the genus Desulfovibrio and classification of this isolate as a representative of a novel species, Desulfovibrio marrakechensis sp. nov., is therefore proposed.

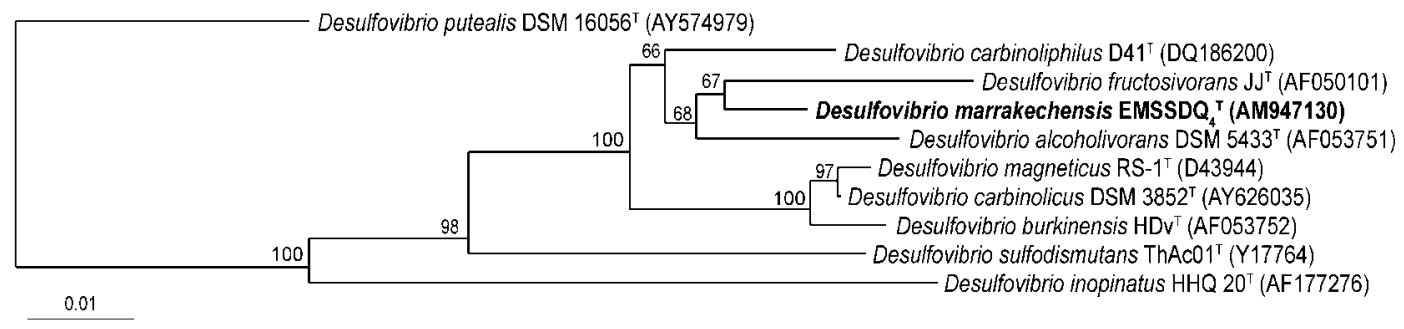

Fig. 1. Unrooted phylogenetic dendrogram, based on 1445 unambiguous base pairs of $16 \mathrm{~S}$ rRNA gene sequence data, indicating the position of Desulfovibrio marrakechensis strain EMSSDQ ${ }_{4}{ }^{\top}$ amongst the most closely related strains of the genus Desulfovibrio. GenBank accession numbers are given in parentheses. Bootstrap values, expressed as percentages of 1000 replications, are shown at branching points. Bar, 1 difference per 100 nucleotide positions. 


\section{Description of Desulfovibrio marrakechensis sp. nov.}

Desulfovibrio marrakechensis [mar.ra.kech.en'sis. N.L. masc. adj. marrakechensis pertaining to Marrakech, in south-west Morocco, the source of isolation of the type strain; also referring to the first sulfate-reducing bacterium isolated from Morocco (Marrakech was the old name of Morocco)].

Cells are straight rods with rounded ends, $1.3-1.6 \times 3.0$ $4.0 \mu \mathrm{m}$, occurring either singly or in pairs, non-motile, Gram-negative, oxidase-negative and catalase-positive. Optimum growth occurs at $37{ }^{\circ} \mathrm{C}$ and $\mathrm{pH} 7$. Grows in 0 $35 \mathrm{~g} \mathrm{NaCl} \mathrm{l}^{-1}$, with optimum growth in the absence of $\mathrm{NaCl}$. Able to use sulfate, sulfite, thiosulfate and elemental sulfur, with production of sulfide. Fumarate also serves as electron acceptor, whereas nitrate and nitrite do not. Strictly anaerobic, but exhibits limited growth in the absence of sulfate under air in basal medium containing lactate and yeast extract. Substrates that are oxidized by anaerobic respiration of sulfate are hydrogen, formate, lactate, pyruvate, fumarate, malate, ethanol, 2-methoxyethanol, 1-propanol, 2-propanol, 1-butanol, 1,2-propanediol, 1,3-propanediol, 1,4-butanediol and 1,4-tyrosol. Hydrogen and formate are only utilized in the presence of acetate. Lactate is oxidized to acetate. 1,4-Tyrosol is transformed to 4-hydroxyphenylacetate at $100 \%$ recovery, leaving the aromatic ring intact. Fumarate, malate and pyruvate are fermented. Acetate, propionate, butyrate, methanol, 2-butanol, glycerol, ethylene glycol, 2,3-butanediol, crotonate, alanine, glycine, arginine, lysine, choline, lactose, sucrose, glucose, fructose, maltose, mannose, ribose, xylose, yeast extract, biotrypticase, Casamino acids, peptone, phenol, catechol, resorcinol, 4-hydroxyphenylacetate, benzoate, 4-hydroxybenzoate, 3-hydroxybenzoate, protocatechuate, syringate, gallate, $o$-methylgallate, veratrate, $p$-anisate, cinnamate, $p$-coumarate, $o$-coumarate, $m$ coumarate, vanillate, ferulate and caffeate are not utilized. Desulfoviridin and cytochrome $c_{3}$ are present.

The type strain is $\mathrm{EMSSDQ}_{4}{ }^{\mathrm{T}}\left(=\mathrm{DSM} 19337^{\mathrm{T}}=\mathrm{ATCC}\right.$ BAA- $1562^{\mathrm{T}}$ ), isolated from an aeration basin in Marrakech, Morocco, used for the elimination of OMW by natural evaporation. The DNA G + C content of the type strain is $65.1 \mathrm{~mol} \%$.

\section{Acknowledgements}

F.C. received a doctoral fellowship (Scientific Research and Management training) from the Moroccan Minister for National Education and A.-I. Q. received a senior fellowship from the French Research Institute for Development (IRD). This work was supported by the PROTARS III (ref D14/15) Moroccan programme. We thank the Gabinete de Relações Internacionais da Ciência e do Ensino Superior of Portugal (GRICES) and the Centre National de la Recherche Scientifique et Technique of Morocco (CNRST) for supporting the mobility of the researchers in this project. The authors also wish to thank Professor Kjeld Ingvorsen for preparing electron micrographs and Professors Allen Toby and Michel Magot for helpful discussions. The authors are grateful to Maria Luisa
Machado, Jennifer Gregor and Jean Lorquin for technical assistance and Nancy Nichols for improving the manuscript.

\section{References}

Abdelkafi, S., Chamkha, M., Casalot, L., Sayadi, S. \& Labat, M. (2005). Isolation and characterization of a novel Bacillus sp., strain YAS1, capable of transforming tyrosol under hypersaline conditions. FEMS Microbiol Lett 252, 79-84.

Allen, T. D., Kraus, P. F., Lawson, P. A., Drake, G. R., Balkwill, D. L. \& Tanner, R. S. (2008). Desulfovibrio carbinoliphilus sp. nov., a benzyl alcohol-oxidizing, sulfate-reducing bacterium isolated from a gas condensate-contaminated aquifer. Int J Syst Evol Microbiol 58, 13131317.

Allouche, N., Damak, M., Ellouz, R. \& Sayadi, S. (2004). Use of whole cells of Pseudomonas aeruginosa for synthesis of the antioxidant hydroxytyrosol via conversion of tyrosol. Appl Environ Microbiol 70, 2105-2109.

Bak, F. \& Pfennig, N. (1987). Chemolithotrophic growth of Desulfovibrio sulfodismutans sp. nov. by disproportionation of inorganic sulfur compounds. Arch Microbiol 147, 184-189.

Balch, W. E., Fox, G. E., Magrum, L. J., Woese, C. R. \& Wolfe, R. S. (1979). Methanogens: reevaluation of a unique biological group. Microbiol Rev 43, 260-296.

Benson, D. A., Boguski, M. S., Lipman, D. J., Ostell, J., Ouellette, B. F. F., Rapp, B. A. \& Wheeler, D. L. (1999). GenBank. Nucleic Acids Res 27, 12-17.

Capasso, R., Evidente, A., Schivo, L., Orru, G., Marcialis, M. A. \& Cristinzio, G. (1995). Antibacterial polyphenols from olive oil mill waste waters. J Appl Bacteriol 79, 393-398.

Chamkha, M., Labat, M., Patel, B. K. C. \& Garcia, J.-L. (2001). Isolation of a cinnamic acid-metabolizing Clostridium glycolicum strain from oil mill wastewaters and emendation of the species description. Int J Syst Evol Microbiol 51, 2049-2054.

Cord-Ruwisch, R. (1985). A quick method for the determination of dissolved and precipitated sulfides in cultures of sulfate-reducing bacteria. J Microbiol Methods 4, 33-36.

Dolla, A., Fournier, M. \& Dermoun, Z. (2006). Oxygen defense in sulfate-reducing bacteria. J Biotechnol 126, 87-100.

Felsenstein, J. (1985). Confidence limits on phylogenies: an approach using the bootstrap. Evolution 39, 783-791.

Fernandez-Bolanos, J., Felizon, B., Brenes, M., Guillen, R. \& Heredia, A. (1998). Hydroxytyrosol and tyrosol as the main compounds found in the phenolic fraction of steam-exploded olive stones. J Am Oil Chem Soc 75, 1643-1649.

Hungate, R. E. (1969). A roll tube method for cultivation of strict anaerobes. Methods Microbiol 3B, 117-132.

Imhoff-Stuckle, D. \& Pfennig, N. (1983). Isolation and characterization of a nicotinic acid-degrading sulfate-reducing bacterium, Desulfococcus niacini sp. nov. Arch Microbiol 136, 194-198.

Jukes, T. H. \& Cantor, C. R. (1969). Evolution of protein molecules. In Mammalian Protein Metabolism, vol. 3, pp. 21-132. Edited by H. N. Munro. New York: Academic Press.

Labat, M., Augur, C., Perraud-Gaime, I., Roussos, S. \& Sayadi, S. (2000). Biotechnological potentialities of polyphenolic compounds of coffee and comparison with olive. In Coffee Biotechnology and Quality, pp. 517-531. Edited by T. Sera, C. R. Soccol, A. Pandey \& S. Roussos. Dordrecht: Kluwer.

Lesage-Meessen, L., Navarro, D., Maunier, S., Sigoillot, J.-C., Lorquin, J., Delattre, M., Simon, J.-L., Asther, M. \& Labat, M. (2001). 
Simple phenolic content in olive residues as a function of extraction systems. Food Chem 75, 501-507.

Liebgott, P.-P., Labat, M., Casalot, L., Amouric, A. \& Lorquin, J. (2007). Bioconversion of tyrosol into hydroxytyrosol and 3,4dihydroxyphenylacetic acid under hypersaline conditions by the new Halomonas sp. strain HTB24. FEMS Microbiol Lett 276, 26-33.

Liebgott, P.-P., Joseph, M., Fardeau, M.-L., Cayol, J.-L., Falsen, E., Chamkh, F., Qatibi, A.-I. \& Labat, M. (2008). Clostridiisalibacter paucivorans gen. nov., sp. nov., a novel moderately halophilic bacterium isolated from olive mill wastewater. Int J Syst Evol Microbiol 58, 61-67.

Loubinoux, J., Valente, F. M. A., Pereira, I. A. C., Costa, A., Grimont, P. A. D. \& Le Faou, A. E. (2002). Reclassification of the only species of the genus Desulfomonas, Desulfomonas pigra, as Desulfovibrio piger comb. nov. Int J Syst Evol Microbiol 52, 1305-1308.

Maidak, B. L., Cole, J. R., Lilburn, T. G., Parker, C. T., Jr, Saxman, P. R., Farris, R. J., Garrity, G. M., Olsen, G. J., Schmidt, T. M. \& Tiedje, J. M. (2001). The RDP-II (Ribosomal Database Project). Nucleic Acids Res 29, 173-174.

Mechichi, T., Fardeau, M.-L., Labat, M., Garcia, J.-L., Verhé, F. \& Patel, B. K. C. (2000). Clostridium peptidovorans sp. nov., a peptidefermenting bacterium from an olive mill wastewater treatment digester. Int J Syst Evol Microbiol 50, 1259-1264.

Mesbah, M., Premachandran, U. \& Whitman, W. B. (1989). Precise measurement of the $\mathrm{G}+\mathrm{C}$ content of deoxyribonucleic acid by highperformance liquid chromatography. Int J Syst Bacteriol 39, 159-167.

Mulinacci, N., Romani, A., Galardi, C., Pinelli, P., Giaccherini, C. \& Vincieri, F. F. (2001). Polyphenolic content in olive oil waste waters and related olive samples. J Agric Food Chem 49, 3509-3514.

Nanninga, H. J. \& Gottschal, J. C. (1987). Properties of Desulfovibrio carbinolicus sp. nov. and other sulfate-reducing bacteria isolated from an anaerobic-purification plant. Appl Environ Microbiol 53, 802-809.

Ollivier, B., Cord-Ruwisch, R., Hatchikian, E. C. \& Garcia, J. L. (1988). Characterization of Desulfovibrio fructosovorans sp. nov. Arch Microbiol 149, 447-450.
Ouattara, A. S., Patel, B. K. C., Cayol, J.-L., Cuzin, N., Traore, A. S. \& Garcia, J.-L. (1999). Isolation and characterization of Desulfovibrio burkinensis sp. nov. from an African ricefield, and phylogeny of Desulfovibrio alcoholivorans. Int J Syst Bacteriol 49, 639-643.

Qatibi, A. I., Nivière, V. \& Garcia, J. L. (1991). Desulfovibrio alcoholovorans sp. nov., a sulfate-reducing bacterium able to grow on glycerol 1,2- and 1,3-propanediol. Arch Microbiol 155, 143-148.

Qatibi, A. I., Bennisse, R., Jana, H. \& Garcia, J.-L. (1998). Anaerobic degradation of glycerol by Desulfovibrio fructosovorans and $D$. carbinolicus and evidence for glycerol-dependent utilization of 1,2propanediol. Curr Microbiol 36, 283-290.

Saitou, N. \& Nei, M. (1987). The neighbor-joining method: a new method for reconstructing phylogenetic trees. Mol Biol Evol 4, 406425.

Sakaguchi, T., Arakaki, A. \& Matsunaga, T. (2002). Desulfovibrio magneticus sp. nov., a novel sulfate-reducing bacterium that produces intracellular single-domain-sized magnetite particles. Int J Syst Evol Microbiol 52, 215-221.

Sayadi, S., Allouche, N., Jaoua, M. \& Aloui, F. (2000). Detrimental effects of high molecular-mass polyphenols on olive mill wastewater biotreatment. Process Biochem 35, 725-735.

Scheline, R. R. (1966). A rapid synthesis of 3-O-methylgallic acid. Acta Chem Scand 20, 1182.

Stackebrandt, E. \& Goebel, B. M. (1994). Taxonomic note: a place for DNA-DNA reassociation and 16S rRNA sequence analysis in the present species definition in bacteriology. Int J Syst Bacteriol 44, 846849.

Thabet, O. B., Fardeau, M. L., Joulian, C., Thomas, P., Hamdi, M., Garcia, J.-L. \& Ollivier, B. (2004). Clostridium tunisiense sp. nov., a new proteolytic, sulfur-reducing bacterium isolated from an olive mill wastewater contaminated by phosphogypse. Anaerobe 10, 185-190.

Widdel, F. \& Pfennig, N. (1981). Studies on dissimilatory sulfatereducing bacteria that decompose fatty acids. I. Isolation of new sulfate-reducing bacteria enriched with acetate from saline environments. Description of Desulfobacter postgatei gen. nov., sp. nov. Arch Microbiol 129, 395-400. 